\title{
Description of the Friesian Horse population of South Africa and Namibia
}

\author{
S.M. Pretorius ${ }^{1 \#}$, E. van Marle-Köster ${ }^{1}$ and B.E. Mostert $^{2}$ \\ ${ }^{1}$ Department of Animal \& Wildlife Sciences, University of Pretoria, Pretoria 0002, South Africa \\ ${ }^{2}$ ARC Animal Improvement Institute, Private Bag X2, Irene 0062, South Africa
}

\begin{abstract}
Data obtained from the Friesian Horse Studbook of Southern Africa and Friesian Horse Breeders' Society of South Africa were analyzed to describe and evaluate the population regarding inbreeding and morphological body measurements. Eight different body measurements (height at withers, height of back, height of croup, body length, length of cannon forelimb and hind limb, circumference of cannon bone foreand hind limb) recorded on 232 horses were included for analyses. The pedigrees of 696 horses were used for estimation of inbreeding coefficients. A total of $25 \%$ of the horses included in the data was inbred, with inbreeding coefficients ranging from $0.07 \%$ to $27.8 \%$. A positive trend in the average inbreeding per year was observed, but the rate of inbreeding was relatively low. Recording of pedigree information will be essential for long-term evaluation of inbreeding in the Friesian Horse and the recording of objective body measurements is recommended for inclusion in selection programs.
\end{abstract}

Keywords: Body measurements, linear scoring, heritability, inbreeding

${ }^{\#}$ Corresponding author. E-mail: tilla_s@mweb.co.za

\section{Introduction}

The Friesian Horse breed originated from Friesland in the Netherlands. The first record of these horses referred to as Friesians, was during mediaeval times, when the knights in armour mostly used Friesian Horses (Douma, 1994). Since then Friesian Horses were subjected to selection for several conformational features suited to the requirements of the moment in time, varying from a horse used in warfare, to sport and agriculture (Douma, 1994). The first herd book for Friesians, namely "Het Friesch Paarden Stamboek" (FPS), was established in 1879 in Roordahuizum, Friesland, with the aim to improve the breed through pedigree recording and implementation of stud registers (Douma, 1994). During 1906 two Friesian stallions were imported to South Africa, followed by several imports of mares and stallions from the Netherlands. In 1980 the Friesian Horse Breeders' Society of South Africa was established consisting of 12 members (Campher et al., 1998) and an additional breeders organization was formed in 1989, namely the Friesian Horse Studbook of Southern Africa (FPSSA). The main differences between the two organizations are that the South African government and South African Studbook recognize the Friesian Horse Breeders' Society of South Africa, while the Friesian Horse Studbook of Southern Africa is affiliated with the FPS and the World Friesian Horse Organization. The organizations further differ in their approach to judging and evaluation of their horses. Only international judges from The Netherlands are recognized by the FPSSA for the evaluation of their horses, while local judges are responsible for the judging Friesian Horses of the Friesian Horse Breeders' Society of South Africa (Dr B.F. Smit, 2001, Personal communication, P.O. Box 4, Piketberg, 7320).

Friesian horses became popular in South Africa for recreation, but were also used in crossbreeding programs with Hackneys, Boerperde and other breeds in an effort to improve draught horses (Campher et al., 1998). In South Africa, Friesian Horses are currently selected mostly on the grounds of their aesthetical value rather than for functional efficiency. Breeders make substantial financial investments and, therefore, there is sufficient reason to evaluate the genetic potential as well as traits for inclusion in selection programs.

Performance and pedigree data of the South African Friesian Horses are limited, as indicated in this study. The aim of this paper was to provide a morphological description (body measurements) of Friesian Horses in South Africa and Namibia and to evaluate inbreeding in the current Southern African population, using the available data.

\section{Material and Methods}

Body measurements were obtained from 232 horses four years of age and older, belonging to 21 stud breeders and 16 horse owners in South Africa and Namibia, representing both breeders' societies (FPSSA 
and the Friesian Horse Breeders' Society of South Africa). Eight body measurements were taken, namely wither height, back height, croup height, body length, cannon bone length of the front and hind limbs and cannon bone circumference of the front and hind limbs (Table 1). All horses were measured on a level, hard surface. Measurements were taken on the left side of the horse and the horses were held by the personnel of the stud or by the horse owners. If horses were not calm enough, a twitch was used. Animals were not sedated. If the measuring process was disturbed, it was repeated. Only in very few cases could some of the measurements not be taken. The method of taking the measurements were similar to that used by Zechner et al. (2001). All measurements were taken by the same person in order to minimize human error. Approximately $20 \%$ of the horses in each stud was measured twice on the same day for data validation.

Table 1 Procedures for obtaining body measurements

\begin{tabular}{|c|c|c|}
\hline Measurement & Measuring device & Anatomical description \\
\hline 1. Height at withers & $\begin{array}{l}\text { Measuring stick } \\
(\mathrm{cm})\end{array}$ & $\begin{array}{l}\text { Distance from the highest point of the processus spinali of the } \\
\text { second to the sixth thoracic vertebra to the floor }\end{array}$ \\
\hline 2. Height of back & $\begin{array}{l}\text { Measuring stick } \\
(\mathrm{cm})\end{array}$ & Distance from the deepest point of the back to the floor \\
\hline 3. Height of croup & $\begin{array}{l}\text { Measuring stick } \\
(\mathrm{cm})\end{array}$ & Distance from the rump (ileum) to the floor \\
\hline 4. Body length & $\begin{array}{l}\text { Metal measuring tape } \\
(\mathrm{cm})\end{array}$ & $\begin{array}{l}\text { Distance from the most cranial point of the sternum to the } \\
\text { most caudal point of the pin bone }\end{array}$ \\
\hline $\begin{array}{l}\text { 5. Length of cannon - } \\
\text { forelimb }\end{array}$ & $\begin{array}{l}\text { Metal measuring tape } \\
(\mathrm{cm})\end{array}$ & $\begin{array}{l}\text { Distance from the lateral tuberculum of the os metacarpal IV } \\
\text { to the middle of the fetlock joint }\end{array}$ \\
\hline $\begin{array}{l}\text { 6. Length of cannon - } \\
\text { hind limb }\end{array}$ & $\begin{array}{l}\text { Metal measuring tape } \\
(\mathrm{cm})\end{array}$ & $\begin{array}{l}\text { Distance from the lateral tuberculum of the os metatarsal IV } \\
\text { to the middle of the fetlock joint }\end{array}$ \\
\hline $\begin{array}{l}\text { 7. Circumference of } \\
\text { cannon bone - } \\
\text { forelimb }\end{array}$ & $\begin{array}{l}\text { Plastic measuring tape } \\
(\mathrm{cm})\end{array}$ & Smallest circumference of the cannon bone of the forelimb \\
\hline $\begin{array}{l}\text { 8. Circumference of } \\
\text { cannon bone - } \\
\text { hind limb }\end{array}$ & $\begin{array}{l}\text { Plastic measuring tape } \\
(\mathrm{cm})\end{array}$ & Smallest circumference of the cannon bone of the hind limb \\
\hline
\end{tabular}

The pedigree information for the study was obtained from both the Friesian Horse Studbook of Southern Africa (FPSSA) and the Friesian Horse Breeders' Society of South Africa. The FPSSA had approximately 540 horses registered with their association at the time of the study, while the Friesian Horse Breeders' Society of South Africa had 192 horses registered with their association on 1 July 2001 (Campher et al., 1989). The pedigree file was compiled from the records provided by the FPSSA, consisting of registration certificates of the FPS, the FPSSA, the South African Stud Book Association or the Friesian Horse Breeders' Society of South Africa, birth notifications of any of the above-mentioned associations, judging sheets and even change of ownership notifications.

Statistical analyses were performed using the statistical programs of the SAS (2001) and inbreeding coefficients were estimated using the Animal Breeder's Tool Kit ${ }^{\circledR}$ (Golden et al., 1992). Rate of inbreeding had been estimated as the regression of average inbreeding on year of birth. Heritability was estimated for the different body measurements using a sire model. Due to limited pedigree information available on Friesian Horses measured in this study, only 80 animals were included in the sire model. These animals originated from 29 sires. For the purpose of fitting the model, the horses were grouped together according to the location of measurement for compiling contemporary groups of reasonable size. Location was defined as the specific farm or Friesian Horse show where horses were measured on the same day from different studs and owners. The use of the animal was defined as a fixed effect as Friesian Horses are mainly used in two categories by breeders and owners, namely recreation and sport. The following sire model was fit to the data, using SAS (2001): 


$$
\mathbf{Y}_{\mathrm{ijkl}}=\mu+\mathbf{L}_{\mathbf{i}}+\mathbf{U}_{\mathbf{j}}+\mathbf{G}_{\mathrm{k}}+\mathbf{S}_{\mathbf{l}}+\mathbf{e}_{\mathrm{ijklm}}
$$

Where $\quad \mathbf{Y}_{\mathbf{i j k l m}}=$ observation of the $m$ th animal $(l=1,2, \ldots 80)$

$\mu \quad=$ the population mean

$\mathbf{L}_{\mathbf{i}} \quad=$ fixed effect of of the $i$ th location of measurement $(i=1,2, \ldots 13)$

$\mathbf{U}_{\mathbf{j}} \quad=$ fixed effect of the $j$ th use of the animal $(j=1,2)$

$\mathbf{G}_{\mathbf{k}} \quad=$ fixed effect of the $k$ th gender $(k=1,2,3)$

$\mathbf{S}_{\mathbf{l}} \quad=$ random effect of the $l$ th sire $(l=1,2, \ldots 29)$

$\mathbf{e}_{\mathbf{i j k} \mathbf{l}} \quad=$ random residual error

\section{Results and Discussion}

In this study, eight different body measurements of 232 horses were measured as described in Table 1. The means, minimums and maximums of all the measurements are shown in Table 2.

Table 2 Descriptive statistics for eight body measurements $(\mathrm{cm})$ for each of the three genders

\begin{tabular}{|c|c|c|c|c|c|c|c|c|}
\hline \multicolumn{9}{|l|}{ Stallions } \\
\hline Variable Label & $\mathbf{N}$ & Mean & Std Dev & Std Error & Var & Min & Max & Skewness \\
\hline Wither-height & 33 & 160.3 & 6.09 & 1.06 & 37.08 & 151 & 169 & -0.02 \\
\hline Back-height & 33 & 148.9 & 4.95 & 0.86 & 24.5 & 140 & 158 & 0.04 \\
\hline Croup-height & 33 & 158.4 & 4.74 & 0.82 & 22.43 & 148 & 167 & -0.12 \\
\hline Body-length & 33 & 165.7 & 6.53 & 1.14 & 42.66 & 153 & 179 & 0.22 \\
\hline CC-FL & 33 & 24.4 & 1.37 & 0.24 & 1.87 & 21.5 & 28.5 & 0.66 \\
\hline CC-HL & 32 & 26.6 & 1.35 & 0.24 & 1.81 & 24 & 29.5 & 0.28 \\
\hline CL-FL & 33 & 31.5 & 1.99 & 0.35 & 3.94 & 25 & 35 & -1.32 \\
\hline CL-HL & 32 & 36.9 & 2.24 & 0.4 & 5.02 & 32 & 41 & -0.29 \\
\hline \multicolumn{9}{|l|}{ Mares } \\
\hline Variable Label & $\mathbf{N}$ & Mean & Std Dev & Std Error & Var & Min & Max & Skewness \\
\hline Wither-height & 176 & 157.4 & 4.81 & 0.36 & 23.13 & 147 & 171 & 0.28 \\
\hline Back-height & 176 & 146.2 & 4.45 & 0.34 & 19.83 & 136 & 161 & 0.45 \\
\hline Croup-height & 176 & 155.3 & 4.22 & 0.32 & 17.81 & 146 & 167 & 0.21 \\
\hline Body-length & 176 & 166.5 & 6.72 & 0.51 & 45.22 & 150 & 182 & -0.11 \\
\hline CC-FL & 175 & 21.8 & 1.04 & 0.08 & 1.09 & 19 & 24 & -0.06 \\
\hline CC-HL & 173 & 24.1 & 1.16 & 0.09 & 1.35 & 21 & 27 & 0.17 \\
\hline CL-FL & 175 & 29.2 & 1.85 & 0.14 & 3.42 & 24 & 33 & -0.15 \\
\hline CL-HL & 174 & 34.6 & 2.12 & 0.16 & 4.5 & 29 & 41 & 0.54 \\
\hline \multicolumn{9}{|l|}{ Geldings } \\
\hline Variable Label & $\mathbf{N}$ & Mean & Std Dev & Std Error & Var & Min & Max & Skewness \\
\hline Wither-height & 23 & 158.6 & 4.93 & 1.03 & 24.35 & 149 & 168 & 0.01 \\
\hline Back-height & 23 & 148.3 & 3.99 & 0.83 & 15.95 & 142 & 156 & 0.29 \\
\hline Croup-height & 23 & 158 & 4.06 & 0.85 & 16.5 & 151 & 169 & 0.85 \\
\hline Body-length & 23 & 163.7 & 6.04 & 1.26 & 36.47 & 149 & 173 & 0.43 \\
\hline CC-FL & 23 & 22.9 & 1.18 & 0.25 & 1.39 & 21 & 25 & 0.21 \\
\hline CC-HL & 23 & 25.1 & 1.03 & 0.21 & 1.05 & 23 & 27 & -0.4 \\
\hline CL-FL & 23 & 30.7 & 1.61 & 0.34 & 2.6 & 28 & 34 & 0.2 \\
\hline CL-HL & 23 & 36.3 & 2.26 & 0.47 & 5.11 & 32 & 41 & 0.42 \\
\hline
\end{tabular}


For all the measurements, with the exception of body length, the means for the geldings were an intermediate value between those of the stallions, which had the highest values, and the mares, which had the lowest values. The mean body length of mares was higher $(\mathrm{P}<0.01)$ than that of the stallions and of the geldings. The lowest wither height measurement of $147 \mathrm{~cm}$ was observed for a mare. Due to a lack of pedigree information for this mare, it cannot be confirmed if she was inbred or not. This emphasizes the importance of the availability of complete records for scientific studies. This is below the minimum wither height of $150 \mathrm{~cm}$ for an animal to be registered in the studbook. It is interesting to note that the highest wither height measurement of $171 \mathrm{~cm}$ was also observed for a mare. This particular mare, however, did not have the highest value for any of the other body measurements and was only five years old at the time of measurement. The mean values for wither height were 5 to $9 \mathrm{~cm}$ smaller than values for body length for all genders. A difference of $10-11 \mathrm{~cm}$ was found between height at withers and height of back for all three genders. The cannon length measurements were proportional to overall size and no obvious deviations were seen. There were also no obvious deviations from the mean in cannon circumference for any of the genders.

In the horse industry, studbook associations and breeders primarily apply subjective linear measurements in the judging and selection of horses. The only exception is wither height, which is the only objective measurement taken on a regular basis by a few breeders and some studbook associations. A panel of judges usually scores the horses and takes the wither height measurement; the owners/breeders then receive linear scoring sheets for their horses, which can then be used to select breeding partners for positive assortative matings.

Selection for strong and powerful movement can lead to a shorter body length, because powerful movement requires that the hindquarters of the horse be sufficiently brought in under the horse to better carry the weight of the body, and thus producing a more powerful movement (De Boer, 2001; 2002). It is interesting to note that the means for the body measurements for the geldings were not higher $(\mathrm{P}>0.05)$ than those of the stallions. In most species, such as cattle, and even in humans, the absence of the hormone testosterone, which is a natural antagonist to growth hormone, can lead to an animal growing taller after castration than it would have had it not been castrated (Batt, 1980; Ganong, 1997). The reason for the lower measurements in geldings can, however, be partly explained by the fact that most horses are only castrated after puberty has been reached (at \pm 4 years of age), unlike for instance cattle and sheep, which are mostly castrated shortly after birth or just before weaning. The results of the measurements show that the Friesian Horse is normally of rectangular (height at withers: body length) format. These results are in accordance with the results found by Zechner et al. (2001) for Lipizzan horses. A difference of $3-8 \mathrm{~cm}$ is expected for dressage horses whereas for carriage driving, a larger difference is acceptable (Zechner et al., 2001). The somewhat larger difference between wither height and body length found in Friesians could be explained by the fact that some of these horses that were measured, are used for riding and others for carriage driving, while some are used for both of these activities.

Another common, but important criterion in horse breeding is the difference between height at withers and height of back. The difference of $10-11 \mathrm{~cm}$ found for all three genders is much higher than the difference of $1-2 \mathrm{~cm}$ found by Zechner et al. (2001) for Lipizzan horses. The only possible explanation for this could be that most of the horses measured in this study are not intensively trained. These horses are mostly used only for recreational riding or experience some light training in either carriage driving or riding for show purposes. The Lipizzan horses measured by Zechner et al. (2001), however, were mostly on a training schedule, resulting in better developed back muscles. The cannon length measurements were proportional to overall size and no obvious deviations were seen. There were also no obvious deviations from the mean in cannon circumference for any of the genders, which can be seen as positive, since there is a strong relationship between cannon circumference and the strength of the bones (Frandson \& Spurgeon, 1992).

Heritability estimates for objective body measurements were obtained from applying the sire model (Table 3). A 90\% confidence interval for the estimated heritabilities all included zero, except for cannon circumference of the forelimb. Due to the small data set, heritability estimates could only be obtained for six of the eight traits. The heritability estimates found in this study were not significant. Estimates reported by various authors indicate that similar traits are in general moderately to highly heritable (Table 4).

These heritability estimates indicate that selection for body measurements could be included in breeding programs of Friesian Horses. Objective body measurements such as height and length have also been effectively applied in selection programs in beef cattle (Winder et al., 1990). Depending on the 
breeding objectives of the breeder, different measurements could be of use in the selection program. For example, in the selection of horses for riding under the saddle, the emphasis will be on a shorter body length as this will result in a more powerful movement (De Boer, 2001; 2002). Objective body measurements could therefore also be considered for maintaining the Friesian Horse breed standards.

Table 3 Estimated heritabilities for body measurements

\begin{tabular}{lcc}
\hline Trait & Heritability & $90 \%$ Confidence interval \\
\hline Wither height & 0.30 & $(-0.108 ; 0.33)$ \\
Croup height & 0.37 & $(-0.082 ; 0.36)$ \\
Body length & 0.48 & $(-0.025 ; 0.42)$ \\
Cannon circumference: forelimb & 0.57 & $(0.03 ; 0.47)$ \\
Cannon circumference: hind limb & 0.45 & $(-0.04 ; 0.40)$ \\
Cannon length: forelimb & 0.35 & $(-0.089 ; 0.35)$ \\
\hline
\end{tabular}

Table 4 Heritability estimates for objective body measurements in horses

\begin{tabular}{|c|c|c|c|}
\hline Trait & Heritability & Breed & Reference \\
\hline \multirow{9}{*}{ Height at withers } & $0.33-0.88$ & Thoroughbred (growing) & Hintz et al. (1978) \\
\hline & 0.40 & Thoroughbred & $\begin{array}{l}\text { Biedermann \& Schmucker } \\
\text { (1989) }\end{array}$ \\
\hline & 0.48 & Arab & Seidlitz et al. (1991) \\
\hline & 0.25 & Trakehner & Kaiser et al. (1991) \\
\hline & 0.89 & Shetland Pony & $\begin{array}{l}\text { Van Bergen \& van Arendonk } \\
\text { (1993) }\end{array}$ \\
\hline & $0.40-0.46$ & Halfbred Riding horse & Kapron et al. (1994) \\
\hline & 0.52 & Lipizzan horse & Zechner et al. (2001) \\
\hline & 0.58 & Andalusian horses & Molina et al. (2003) \\
\hline & $034-0.72$ & Pony breeds in France & Anne (2004) \\
\hline \multirow[t]{2}{*}{ Height at croup } & 0.34 & Thoroughbred & $\begin{array}{l}\text { Biedermann \& Schmucker } \\
\text { (1989) }\end{array}$ \\
\hline & 0.15 & Lipizzan horse & Zechner et al. (2001) \\
\hline \multirow[t]{4}{*}{ Heart girth } & 0.13 & Arab & Seidlitz et al. (1991) \\
\hline & 0.30 & Trakehner & Kaiser et al. (1991) \\
\hline & $0.56-0.63$ & Halfbred Riding horse & Kapron et al. (1994) \\
\hline & 0.48 & Andalusian horses & Molina et al. (2003) \\
\hline \multirow{4}{*}{$\begin{array}{l}\text { Cannon bone } \\
\text { circumference }\end{array}$} & $0.12-0.77$ & Thoroughbred (growing) & Hintz et al. (1978) \\
\hline & 0.51 & Arab & Seidlitz et al. (1991) \\
\hline & $0.36-0.62$ & Halfbred Riding horse & Kapron et al. (1994) \\
\hline & $0.36-0.52$ & Lipizzan horse & Zechner et al. (2001) \\
\hline Body length & 0.72 & Andalusian horses & Molina et al. (2003) \\
\hline Body weight & $0.13-0.90$ & Thoroughbred (growing) & Hintz et al. (1978) \\
\hline
\end{tabular}

Pedigree analysis is an important tool to describe genetic variability and its evolution across generations. It also provides useful information for estimation of inbreeding, population structures in terms of census, generation interval, pedigree completeness level and effective population size (Gutiérrez et al., 2003). In the present study inbreeding coefficients were calculated for horses born between 1969 and 2002. In total, 852 pedigree records were included, consisting of $68 \%$ mares, $28 \%$ stallions and colts and $4.7 \%$ geldings. It can be assumed that the number of geldings included is an underestimation of the number of Friesian geldings present in South Africa, since geldings are frequently not registered with any association, because they cannot produce any progeny and are mostly only used for recreational riding. Only 21 horses have been reported dead. Of the 852 records included, $29.5 \%$ had unknown parents and grandparents. Of the remaining $70.8 \%, 36.9 \%$ had a complete two-generation pedigree, $8.8 \%$ had only their parents known and 
$7.0 \%$ had only one known parent. Both parents were known for $86.5 \%$ of the records, while only information from the sire and dam's families was known for $28.0 \%$ and $3.7 \%$, respectively. A total of 156 animals from The Netherlands, that were part of the pedigree file as ancestors of some of the South African horses, was removed from the database in order to calculate the completeness level of the South African pedigrees. The completeness level was calculated from a file consisting of 696 horses (Figure 1).

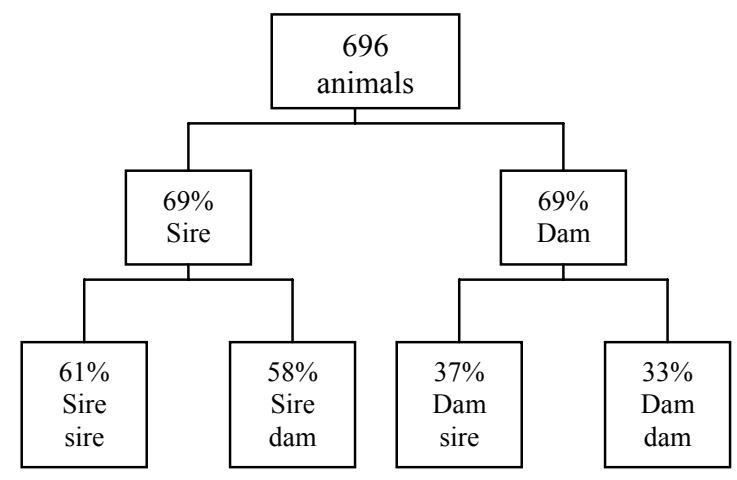

Figure 1 Pedigree completeness level in the South African Friesian Horse population for records from 1969 to 2002

A total of $25.7 \%$ (219) of the Friesian Horses studied, was inbred. The inbreeding coefficients of inbred animals varied from as low as $0.07 \%$ to as high as $27.9 \%$. The rate of inbreeding for this population shows a positive trend of approximately $0.011 \%$ per year (Figure 2 ). This accounts to approximately $0.077 \%$ per generation, with an average generation interval of seven years (Osinga, 2000). This rate of inbreeding is still well below the recommended level of $0.3 \%$ per year (Van der Westhuizen \& Mostert, 1998). This relatively low rate of inbreeding is probably a conservative estimation, due to the incomplete pedigrees, as incomplete pedigree information reduces estimates of inbreeding (Lutaaya et al., 1999).

Investigation of the pedigrees of the 219 inbred animals indicated eight individuals that were the result of father $\mathrm{x}$ daughter matings. There were also 12 matings between daughters and half-brothers of one certain Dutch stallion, resulting in high inbreeding in this specific family line. These matings have the potential for the occurrence of detrimental effects as it leads to an increase in homozygosity for certain traits (Bourdon, 2000). In Figure 3 individual peaks are shown with inbreeding coefficients as high as $25 \%$ in 1981, but on closer investigation it was discovered that there was only one inbred individual in this year and this horse was the result of a father $\mathrm{x}$ daughter mating. Historically the Friesian Horse in The Netherlands was bred from a relatively small baseline with three stallion lines dominating, namely the Tetman-line, the Age-line and the Ritske-line. It is important to mention that of these three lines, the Age-line was very "thin", with only a few stallions in the line, while the influential stallion, Ritske, did not beget many dominant stallions (Osinga, 2000). The South African Friesian population originated from The Netherlands and is therefore subjected to a similar situation as its Dutch counterparts. Only a limited number of Friesian Horses was imported originally and the stallions were used by many breeders, which potentially could have limited the gene pool.

It should, however, also be noted that especially in the early stages of the establishment of the Friesian Horse in South Africa, some breeders practiced crossbreeding. This might have been advantageous to the gene pool of Friesians in South Africa and may partially explain the lower inbreeding estimates.

Horse breeders rarely apply inbreeding as a purposeful mating practice. However, linebreeding is often used to keep the relationship high between an offspring and a particular outstanding ancestor (Tolley, 1984). It has been shown in studies of beef cattle that the rate of inbreeding over time is usually low with no significant potential for inbreeding depression (Burrow, 1993; 1998). Slow inbreeding allows selection to remove the less fit animals and thus at any given mean level of inbreeding, less inbreeding depression is expected among the animals where inbreeding effects have accumulated over a number of generations. The rate of inbreeding and not the actual level of inbreeding in a population is therefore the population parameter for monitoring and control of inbreeding (Burrow, 1998; Mostert, 2004). 


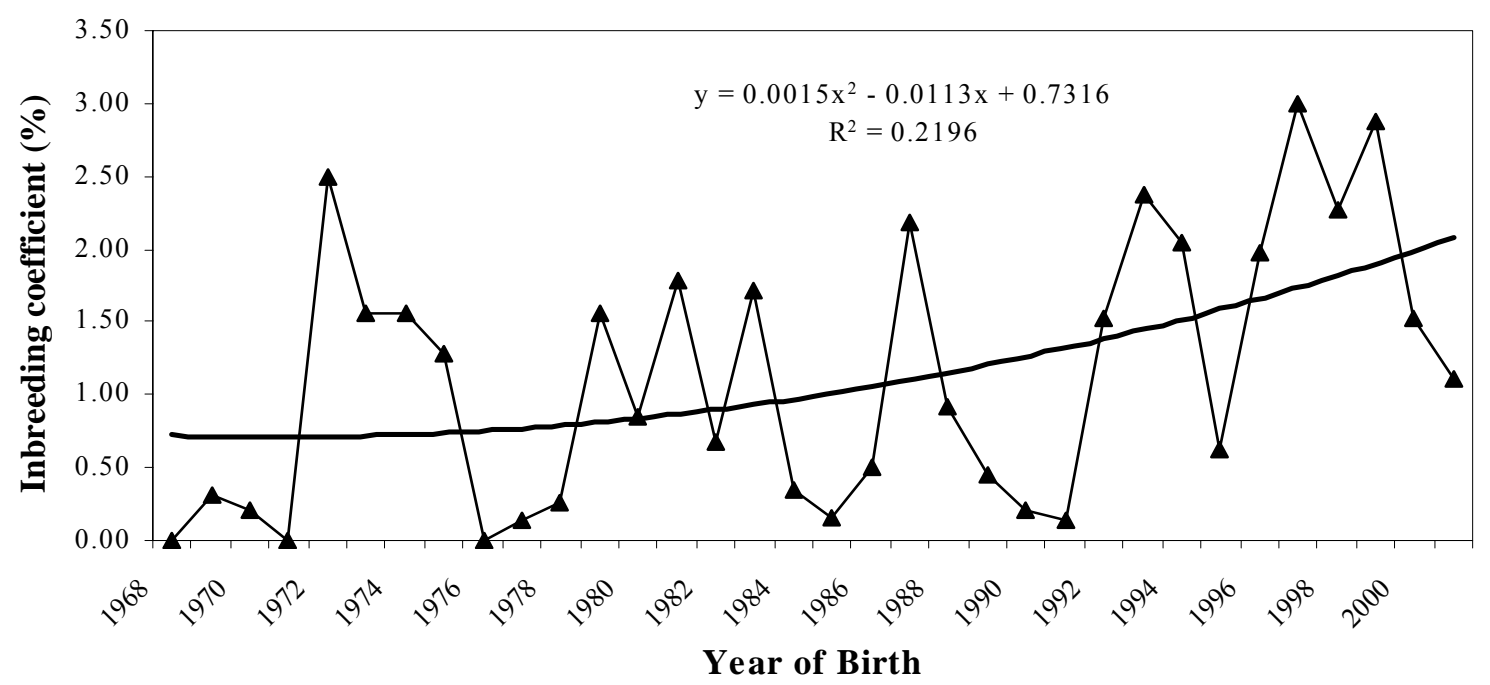

Figure 2 Average rate of inbreeding in the Friesian Horse population of South Africa from 1969 to 2001

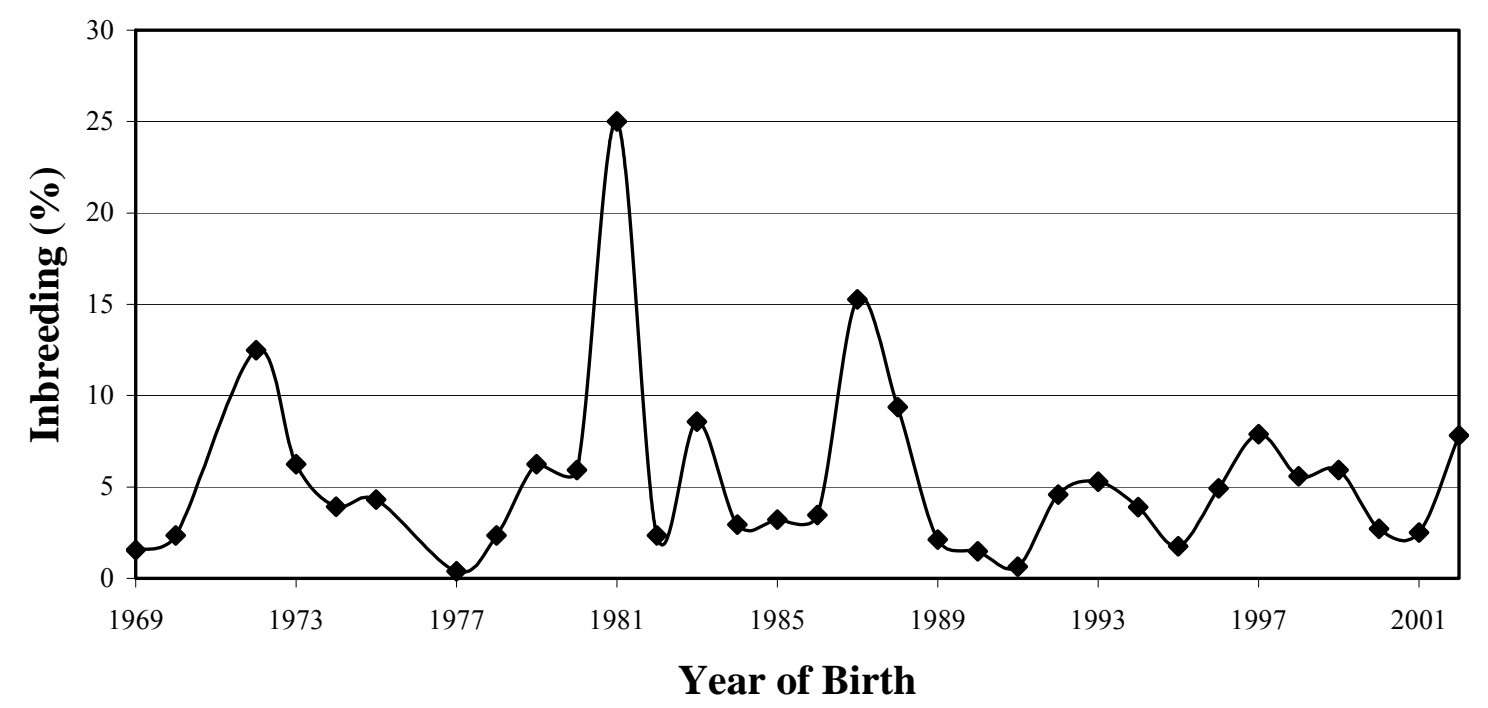

Figure 3 Average inbreeding percentages of all the inbred Friesian Horses born per year from 1969 to 2002

\section{Conclusion}

It can be concluded that the Friesian Horse breeders should consider including objective body measurements in their selection programs. Although the rate of inbreeding over time is low, individual breeders should be aware of potential inbreeding depression. Horses are very different from other livestock species in the sense that no consumable product is produced. When breeding horses, the emphasis is on the aesthetic value, and the "functional use" to humankind. A horse often is a human companion and friend. This results in a more subjective and almost philosophical approach taken in the selection and breeding of horses. The problem with subjective measurement is that it always leaves room for human error or bias. In order to maximize the potential of the Friesians in southern Africa, a central record database should be kept, including pedigrees and body measurements. Accurate and complete data recording will facilitate future genetic evaluations and progress for the breed. 


\section{References}

Anne, R., 2004. Heritability of jumping ability and height of pony breeds in France. Livest. Prod. Sci. (in press).

Batt, R.A.L., 1980. Influences on animal growth and development. Edward Arnold Publishers, London.

Biedermann, Von G. \& Schmucker, F., 1989. Körpermaße von Vollblutpferden und deren Beziehung zur Rennleistung. Züchtungskunde 61, 181-189.

Bourdon, R.M., 2000. Understanding animal breeding. Prentice Hall. 17, 333-342.

Burrow, H.M., 1993. The effects of inbreeding in beef cattle. Anim. Breed. Abstr. 61, 737.

Burrow, H.M., 1998. The effects of inbreeding on productive and adaptive traits and temperament of tropical beef cattle. Livest. Prod. Sci. 55, 227-243.

Campher, J.P., Hunlun, C. \& Van Zyl, G.J., 1998. South African Livestock Breeding. South African Stud Book \& Livestock Improvement Association, Bloemfontein.

De Boer, P.J., 2001. Beoordeling van het Friese Paard in zijn exterieur en beweging. Schoolings document voor juryleden van het FPS.

De Boer, P.J., 2002. Beginners course in Linear Scoring of Friesian horses. Kyalami, South Africa.

Douma, A.K.W., 1994. Paarden van eigen bodem; Het Friese Paard in kort bestek. Koninklijke Vereniging "Het Friesch Paarden-Stamboek", Drachten. pp. 9-21.

Frandson, R.D. \& Spurgeon, T.L., 1992. Anatomy and Physiology of Farm Animals. Lea \& Febiger, Philadelphia. pp. 55-81.

Ganong, W.F., 1997. Review of Medical Physiology. Appleton \& Lange, Stamford, CT. pp. 359-372.

Golden, B.L., Snelling, W.M. \& Mallinckrodt, C.H., 1992. Animal breeder's tool kit user's guide and reference manual. Colorado State University Agricultural Experiment Station Technical Bulletin LTB 92-2.

Grosshauser, S. \& Von Butler-Wemken, I., 1991. Untersuchungen zur exterieurbeurteilung beim süddeutschen kaltblut. Bayerische Landwirtschaft Jahrbuch 68, 507-514.

Gutiérrez, J.P., Altarriba, J., Díaz, C., Quintanilla, R., Canón, J. \& Piedrafita, J., 2003. Pedigree analysis of eight Spanish beef cattle breeds. Gen. Sel. Evol. 35, 43-63.

Hintz, R.L., Hintz, H.F. \& Van Vleck, L.D., 1978. Estimation of heritabilities for weight, height and front cannon bone circumference of Thoroughbreds. J. Anim. Sci. 47, 1243-1245.

Kaiser, Von M., Duda, J. \& Von Butler-Wemken, I., 1991. Genetische und nicht genetische Einflüsse auf die Körpermaße einer Trakehner Zuchtpferdepopulation. Züchtungskunde. 63, 335-341.

Kaproń, M., Pieta, M. \& Kaproń, H., 1994. Genetic relations between conformation traits of half-breed horses. Genetica Polonica 35, 109-114.

Koenen, E.P.C., Van Veldhuizen, A.E. \& Brascamp, E.W., 1995. Genetic parameters of linear scored conformation traits and their relation to dressage and show-jumping performance in the Dutch Warmblood Riding Horse population. Livest. Prod. Sci. 43, 85-94.

Lutaaya, E., Miszatal, I, Bertrand, J.K. \& Mabry, J.W., 1999. Inbreeding in populations with incomplete pedigrees. J. Anim. Breed. Genet. 116, 475-480.

Molina, A., Valera, M., Dos Santos, R. \& Rodero, A., 2003. Genetic parameters of morphofunctional traits in Andalusian horse. Livest. Prod. Sci. 60, 295-303.

Mostert, B.E., 2004. Inbreeding in the South African Ayrshire breed. Dairy Mail, June 2004,138-139.

Osinga, A., 2000. Het fokken van het Friese paard. Scaafsma \& Brouwer Grafishe Bedrijven, Dokkum. pp. 43-90.

Preisinger, R., Wilkens, J. \& Kalm, E., 1991. Estimation of genetic parameters and breeding values for conformation traits for foals and mares in the Trakehner population and their practical implications. Livest. Prod. Sci. 29, 77-86.

Seidlitz, G., Willeke, H. \& Von Butler-Wemken, I., 1991. Köpermaße und exterieurbeurteilungen bei zuchtstuten des Arabischen Vollblutpferdes. Archiv für Tierz. 34, 233-240.

SAS, 2001. Statistical Analysis Systems user's guide (Version 8.2, TS2MO). SAS Institute Inc., Cary, NC, USA.

Tolley, E.A., 1984. Applied genetics and horse breeding: A Review. Equine Vet. Sci. 4, 172-175.

Van Bergen, H.M.J.M. \& Van Arendonk, J.A.M., 1993. Genetic parameters for linear type traits in Shetland Ponies. Livest. Prod. Sci. 36, 273-284.

Van der Westhuizen, J. \& Mostert, B.E., 1998. Inbreeding and the stud breeder. Charolais J. 12-14. 
Von Butler-Wemken, I., Duda, J. \& Kaiser, M., 1992. Genetische analysen für exterieurgesamentbeurteilungen und beziehungen $\mathrm{zu}$ körpermaßen bei trakehner stuten. Züchtungskunde 64, 92-100.

Winder, J.A., Brinks, J.S., Bourdon, R.M. \& Golden, B.L.,1990. Genetic analysis of absolute growth measrements, relative growth rate and restricted selection indices in Red Angus Cattle. J. Anim. Sci. 68,330 .

Zechner, P., Zohman, F., Sölkner, J., Bodo, I., Habe, F., Marti, E. \& Brem, G., 2001. Morphological description of the Lipizzan horse population. Livest. Prod. Sci. 69, 163-177. 